\title{
Correction to: An Analytical Review of Different Approaches to Wastewater Discharge Standards with Particular Emphasis on Nutrients
}

\author{
Michał Preisner $\mathbb{D}^{1} \cdot$ Elena Neverova-Dziopak ${ }^{2} \cdot$ Zbigniew Kowalewski $^{2}$
}

Published online: 20 September 2020

(c) The Author(s) 2020

Correction to: Environmental Management https://doi.org/10.1007/s00267-020-01344-y

The original version of the article has a missing citation referring to the review method. The missing reference should be added after the fourth sentence in the Methods section as: Smol M et al. (2020) Circular economy model framework in the European water and wastewater sector. J Mater Cycles Waste Manag. 22, 682-697. https://doi.org/ 10.1007/s10163-019-00960-z.

Moreover, from the acknowledgements section the authors would like to remove the incorrect information about the financial support of this study under the project: "Monitoring of water and sewage management in the context of the implementation of the circular economy assumptions" (MonGOS), No. PPI/APM/2019/1/00015/U/00001/ZU/00002
(2020-2021), which is financed by the Polish National Agency for Academic Exchange (NAWA) under the International Academic Partnerships Programme. The rest of the acknowledgements section remains without changes.

Open Access This article is licensed under a Creative Commons Attribution 4.0 International License, which permits use, sharing, adaptation, distribution and reproduction in any medium or format, as long as you give appropriate credit to the original author(s) and the source, provide a link to the Creative Commons license, and indicate if changes were made. The images or other third party material in this article are included in the article's Creative Commons license, unless indicated otherwise in a credit line to the material. If material is not included in the article's Creative Commons license and your intended use is not permitted by statutory regulation or exceeds the permitted use, you will need to obtain permission directly from the copyright holder. To view a copy of this license, visit http://creativecommons. org/licenses/by/4.0/.
The original article can be found online at https://doi.org/10.1007/ s00267-020-01344-y.

Michał Preisner

preisner@meeri.pl

1 Mineral and Energy Economy Research Institute, Polish Academy of Sciences, ul. Wybickiego 7A, Cracow 31-261, Poland

2 AGH University of Science and Technology, al. Mickiewicza 30, Cracow 30-059, Poland 